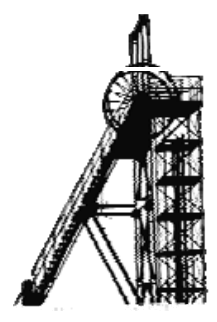

\title{
Americanismos en las guajiras flamencas: arte entre dos continentes
}

\author{
Fernando Cid Lucas \\ Asociación Española de Orientalistas (UAM)
}

Enviado: 12-07-2019

Aceptado: 06-12-2019

\section{Resumen}

En el presente artículo se analiza la presencia de americanismos insertos en las letras de algunas de las guajiras flamencas más conocidas en el repertorio pasado y actual del flamenco. Por otra parte, se comentarán algunos errores de pronunciación de dichos vocablos venidos desde el continente americano en los que han caído cantaores y cantaoras flamencos.

Palabras clave: guajira; flamenco; cantes de ida y vuelta.

\section{Abstract}

In this article we will analyze the presence of several Americanisms inserted in the lyrics of some of the best known flamenco guajiras in the past and current repertoire of flamenco. In the same way, some solutions will be given to some errors of pronunciation of those words coming from the American continent made by flamenco singers.

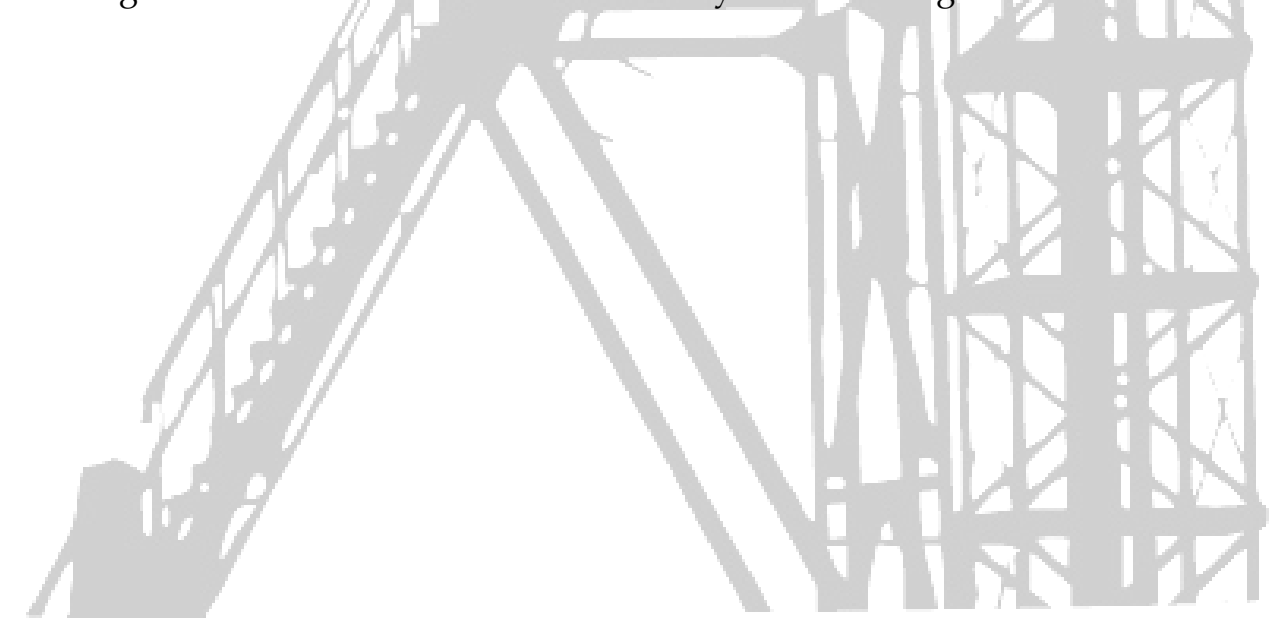


Cuba linda, te venero por tu belleza sin par $^{1}$

\section{Introducción}

En abundantes publicaciones y en webs de aficionados al flamenco se afirma que no hay un palo más bello ${ }^{2}$, por lo que tiene de mestizo, por lo florido de su entonación y por lo que nos hace soñar y sentir al escucharlo en una buena interpretación, que la guajira ${ }^{3}$. Tal vez a muchos -como a quien escribe estas páginas- les llega un sentimiento nostálgico y romántico que tiene que ver con recordar a sus abuelos (bisabuelo, ya en mi caso) cuando fueron hasta Cuba para emprender algún negocio porque aquí no podían, o a luchar en una guerra lejana y dura, y volvieron a casa (aquellos que lo hicieron) contando lo distinta que era aquella tierra y sus gentes con respecto a la que les vio nacer ${ }^{4}$.

La guajira flamenca -como la misma isla de Cuba- es un ejemplo de mezcolanza en lo musical y también en la expresión de sus letras, en donde el español peninsular conviye con un buen número de vocablos indígenas que, en armonía, van trenzando un cadencioso y envolvente canto para quien lo escucha. Este hecho, esta comunión entre las lenguas será lo que vertebre el presente artículo, sobre todo la presencia de términos cubanos o caribeños en las letras de las guajiras flamencas que todavía se siguen cantando en el siglo XXI; aunque también/señalaremos alguna que otra incursión extranjera siempre relativa al léxico campesino- presente en estas tonadas flamencas.

\footnotetext{
${ }^{1}$ Letra de guajira interpretada, entre otros, por Pepe Marchena cuya autoría, según la SGAE, se es del compositor y arreglista Joaquín Alfonso Navas, el propio Pepe Marchena (José Tejada Martín) y del letrista José Arroyo García.

2 Véase, por ejemplo, Linares y Núñez (1998); Navarro García (2002). También los comentarios al respecto de las webs: http://www.flamencopolis.com/archives/273 (última consulta: 07/04/2019); y http://www.flamenlove.com/2019/02/guajiras-primera-parte.html (última consulta: 08/04/2019).

${ }^{3}$ Según el Diccionario de la RAE, el "guajiro" (palabra de procedencia cubana), sería la: "persona que vive $y$ trabaja en el campo o que procede de una zona rural". En: https://dle.rae.es/?w= guajiro (última consulta: 18/03/18).

4 Véase Feijóo Gómez (1992).
} 


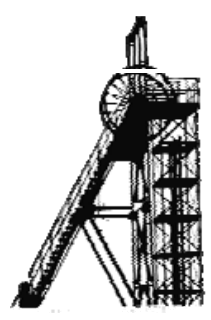

En lo formal, las guajiras (cubanas y flamencas) siguen la estructura versal de la añosa décima o espinela castellana, con un esquema de rima consonante de abbaaccddc construida con diez versos octosílabos; así, una o varias décimas construyen la interpretación de una guajira flamenca. Una estructura que comparte con un claro antecedente suyo, el punto cubano ${ }^{5}$, indudablemente influido por la música autóctona de Andalucía y de Canarias que llevaron hasta el Caribe los emigrantes, que sirvió para asentar las bases de la estrofa que tratamos en este artículo.

Cabe decir que la décima, con distintas variantes en su rima, ha sido muy empleada en Latinoamérica para las sesiones de versos improvisados, con música o a capela; es la forma que se emplea, por ejemplo, en las "improvisaciones de décimas" en Cuba, en la "Payada" de Argentina, Uruguay, sur de Brasil y una parte de Paraguay ${ }^{7}$ (aunque no sólo es la décima la estrofa utilizada), o, en "la Madre Patria", en el "Trovo alpujarreño" 8 de Granada y Almería. En definitiva, está muy ligada a la música y a la canción, y tiene que ver primero con la guajira cubana y luego con la guajira flamenca, con

\footnotetext{
${ }^{5}$ Véase Linares Savio (1999).

${ }^{6}$ Léanse con atención los consejos del payador Andrés Díaz Marrero para escribir o improvisar una décima (en: http://wwwlacasadelpayador.blogspot.com/2006/08/decimasversosoctosilabicos-y-rimas.html; última consulta: 12/07/2019):
}

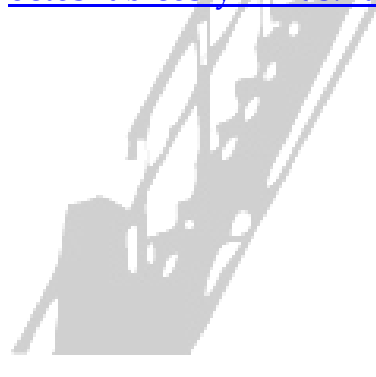

$$
\begin{aligned}
& \text { Cuando quieras escribir } \\
& \text { una décima bonita } \\
& \text { que te salga redondita } \\
& \text { diez versos tienes que unir. } \\
& \text { Para que logres seguir } \\
& \text { rímalos en consonante; } \\
& \text { su octosílabo vibrante, } \\
& \text { cumbre del Arte Menor, } \\
& \text { será un gorjeo de amor } \\
& \text { para que el alma lo cante. }
\end{aligned}
$$

${ }^{7}$ Véase Moya (1959).

${ }^{8}$ Donde no sólo se emplea esta estrofa. 
el espíritu de la improvisación, con el cante y el divertimento de la isla caribeña ${ }^{9}$.

Analizadas desde su ejecución, es un palo al que no le va nada mal sonar junto a la guitarra ${ }^{10}$, las maracas y las claves cubanas, como se hace, por ejemplo, en las animadas guajiras flamencas que cantó y bailó Marisol en su película Marisol rumbo a Río (de 1963) ${ }^{11}$. Como la trama de la citada película que protagonizó la niña prodigio española, la guajira flamenca es uno de los palos denominados "de ida y vuelta". Se explica su idiosincrasia porque el flamenco marchó en las maletas de los emigrantes españoles a diferentes puntos del continente americano y regresó, en este caso desde Cuba (colonia española hasta 1898), con las influencias de sus sones, por ejemplo, del ya aludido "punto cubano" y de otras formas musicales (algunas de ellas hundirían sus raíces en los cantos negros de los esclavos africanos llevados hasta la isla para trabajar en las plantaciones, con sus "ayes" y las múltiples repeticiones de algunas de sus estrofas, que recuerdan a los cánticos de los campos de siembra ${ }^{12}$ ). Además de los ritmos, de lo meramente musical, también llegaron a esta esquina del flamenco abundantes palabras relativas a los cultivos de los campos, a la flora, a la fauna, a los utensilios cotidianos y algunas formas del argot cubano, que la mayoría de los

\footnotetext{
9 Por falta de espacio no nos podemos referir en profundidad a este ámbito, pero puede verse al respecto Díaz Pimienta (1998).

10 Pero se debe hacer de una determinada manera, según se canta en una guajira flamenca bastante conocida. Casi podríamos decir que se trata de una preceptiva en miniatura de la guajira flamenca en cuanto al tempo de la voz y la forma en la que hay que tocar la guitarra como acompañamiento cuando se canta:

$$
\begin{aligned}
& \text { Guajirillo de mi pensamiento, } \\
& \text { canta, canta despacito. } \\
& \text { La guitarra no ha de rasguear, } \\
& \text { porque el cante quiere puntear. }
\end{aligned}
$$

(En: https://www.youtube.com/watch?v=Nf2WNbEh2Os; voz de María José Pérez y al toque Antonio Carrión; última consulta: 19/06/2019).

${ }^{11}$ En: https://www.youtube.com/watch?v=Xrru5tM8FTA (última consulta: 12/02/2019).

12 Véase Castellanos y Castellanos (1994); Casielles (2010).
} 


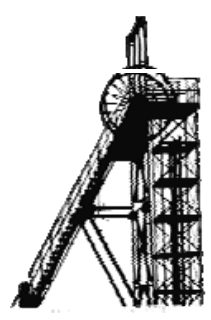

cantaores españoles, lamentablemente, no pronuncian con propiedad, privando de la belleza y de la "caricia" de esa cadencia fonética al auditorio.

A continuación, nos referiremos a algunas de ellas y también a cómo han sido alteradas por nuestros cantaores y cantaoras en las diferentes versiones que se han realizado de dichas guajiras flamencas tradicionales. Precisamente la dificultad para la identificación de estos vocablos -ahora raros- a la hora de su sistematización por la incorrecta pronunciación que se hace de ellos -imprecisa o deformada en muchos casos- ha sido el mayor hándicap a la hora de redactar este ensayo. Del mismo modo, es de rigor informar al lector que en todo momento se han intentado esclarecer todas aquellas palabras que dificultaban la comprensión de la canción (aunque no siempre se ha conseguido), pero ajustándonos también a las limitaciones del espacio y a las de tiempo, siendo muy consciente de que un estudio pormenorizado de esta cuestión sería un bonito argumento para tratar con atención en una (o varias) tesis doctorales o monografías.

Comencemos, por ejemplo, con la impecable y limpia interpretación de una guajira flamenca realizada por el joven cantaor Israel Fernández, dotado de una voz de interesantes matices, rotunda pero aterciopelada a la vez, acompañada en el toque por Rubén Lara ${ }^{13}$, a la que yo nada puedo cuestionar salvo el hecho de la citada pronunciación inadecuada de los cubanismos. En un momento de dicha guajira, Fernández, en el tercer verso de la estrofa que trasladaremos más adelante, equivoca la pronunciación al decir "Guacanayá" y, con ello, se propicia la pérdida de la rima en consonante que pide este cante, debiendo quedar así:

\section{Yo soy el indio más fuerte de las lomas del Guayabo, y vengo a Guacanayabo sólo, gitana, por verte ${ }^{14}$.}

\footnotetext{
${ }^{13}$ En: https://www.youtube.com/watch?v=6g94Ic4VsQ4 (última consulta: 03/05/2019).

${ }^{14}$ En: https://www.youtube.com/watch?v=6g94Ic4VsQ4 (última consulta: 03/05/2019).
} 
Esta interesante guajira ya fue grabada mucho antes que por Fernández por ese grande del flamenco que fue Pepe Pinto (1903-1969), pero con una pronunciación notoriamente diferente:

Yo soy el indio más fuerte de las lomas del Guayabo, y vengo a Guacanayao que sólo, indígena ${ }^{15}$, por verte ${ }^{16}$.

Habrá que coincidir en que esta guajira flamenca en versión de Pepe Pinto -tal vez la más fiel a la letra original- es una joya fruto de la mezcolanza entre el español peninsular y los términos cubanos, justo lo que pretendemos demostrar en este ensayo, en donde se puede apreciar cómo iban de la mano ambas culturas en estas canciones. Pero reconozco que, con el pasar del tiempo, y por la fuerza motriz de la tradición oral, estas letras han ido transformándose, en ocasiones hasta llegar a ser una sombra de lo que fueron en origen. Así, siguiendo con la misma guajira flamenca, en un verso siguiente, en la versión de Fernández se dice que la madre del "indio más fuerte" era de procedencia gitana, mientras que en la versión de Pepe Pinto (y en otras también antiguas), la madre era una "mujer francesa" ${ }^{17}$ :

$$
\begin{aligned}
& \text { Mi "mare"18 no fue cubana, } \\
& \text { que fue una mujer francesa, } \\
& \text { que con dignidad y nobleza } \\
& \text { vino al pueblo de La Habana; } \\
& \text { y ella con su suerte ufana } \\
& \text { yo "chiquetito"19 y bebía } \\
& \text { de sus pechos los licores }
\end{aligned}
$$

\footnotetext{
${ }^{15}$ Lo más notable es que en la versión de Pepe Pinto aparece la palabra "indígena", las indias hermosas, de piel oscura por las que los españoles perdían la cabeza. En la versión de Fernández, españolizada, esta palabra se cambia por "gitana", más en la tradición del sur de España, pero que hace que pierda un tanto el "sabor" de la guajira tal y cómo esta se definiría.

${ }^{16}$ https:// www.youtube.com/watch?v=C3woCWWQIUM (última consulta 08/05/2019).

17 Letra que tiene mucho sentido. No olvidemos que desde la revolución de Haití de 1791 la presencia francesa en Cuba fue cada vez más notable. Véase Álvarez Estévez y Guzmán Pascual (2010).

18 Madre.

${ }^{19}$ Pequeñito, siendo niño.
} 
y murió llena de honores honrando la patria mía ${ }^{20}$.

Tal vez porque Cuba ya no era el destino o el sueño de tantos españoles y las relaciones, otrora tan estrechas, se fueron enfriando, también estas palabras fueron cayendo en el olvido. Como ejemplo de lo que analizaremos en este trabajo, trascribimos ahora la letra completa de dos guajiras flamencas en versión del citado Pepe Pinto, pertinentemente anotadas, para su mejor comprensión:

$$
\begin{aligned}
& \text { Yo soy el indio más fuerte } \\
& \text { de las lomas del Guayabo, } \\
& \text { y vengo a Guacanayao } \\
& \text { que sólo, indígena, por verte. } \\
& \text { Si es que tengo la buena suerte } \\
& \text { de hallar en ti compasión, } \\
& \text { yo te doy mi corazón, } \\
& \text { que el mío mi alma encierra. } \\
& \text { Son tuyas todas mis tierras } \\
& \text { y tuyo mi corazón. } \\
& \text { Desde Santiago de Cuba } \\
& \text { hasta llegar a Pinar del Río } \\
& \text { no hay tabaco como el mío, } \\
& \text { "dicío"21 por los que lo fuman. } \\
& \text { Es más dulce que la uva } \\
& \text { y más dulce que el melón. } \\
& \text { Yo sé también que es } \\
& \text { más dulce que el marañón } \\
& \text { y es más rico que la piña } \\
& \text { Luego lo fuma mi niña } \\
& \text { y le da el mal de corazón. }
\end{aligned}
$$

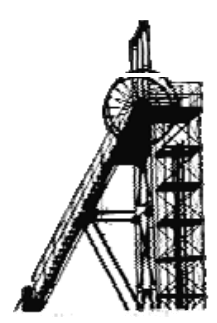

Concordamos en que Guacanayabo no es pronunciar Sevilla o Palamós, por supuesto; y que a un cantaor de nuestros días no se le puede exigir tampoco

${ }^{20}$ En: https:/ iniciacionalflamenco.blogspot.com/2011/11/pequena-guia-13-cantes-varios.html (última consulta: 10/06/2019).

21 "Dicho".

${ }^{22}$ No se refiere al fruto de la vid, sino al de la Coccoloba uvifera o "uva de playa", también conocida en Cuba como guiabara, de frutos suculentos y muy dulces.

${ }^{23}$ El marañón también es conocido por los nombres de anacardo, cágüil o merey. Es originario del nordeste de Brasil y del sur de Venezuela. Su semilla es el preciado fruto seco anacardo. 
que tenga conocimientos profundos de la geografía del Caribe o de la historia compartida entre América y España. Pero sí habrá acuerdo en que cobraría pleno sentido la estrofa y se cerraría la cuestión de la rima en consonante. Que hasta el mejor maestro pone un borrón es cierto, nadie está libre. El mismo Manuel Escacena, grande entre grandes, dice en otras famosas guajiras flamencas que le gusta "pasear por la sabana con mi tabaco encendío", un bioma este de la sabana que no alcanza a Cuba y una palabra que, como sabemos, debería ocupar la capital cubana: La Habana.

Volviendo a las primeras guajiras flamencas, la aludida zona de las Lomas del Guayabo es una zona agreste, de gente aguerrida y dura, donde se encuentra el Salto del Guayabo, donde el enamorado posee alguna plantación (y donde, por otro lado, existieron y existen aún plantaciones muy fecundas) que le ofrece a su enamorada, que vive en la zona del Golfo de Guacanayabo, más cálida y rica en pesca. Se cumpliría así, como en otras tantas composiciones (poéticas o musicales) el tópico del enamorado que recorre un largo trecho para poder ver a su amada, en este caso, desde la zona de la cascada más alta de la isla hasta una zona que se encuentra a nivel del mar.

En definitiva, el "cante de ida y vuelta" viene a testimoniar lo que para muchos puede resultar una obviedad: que la música y el canto acompaña al hombre donde quiera que éste vaya, y que es un barro moldeable, que admite con agrado influencias de otras músicas o voces. El caso que vamos a analizar en este breve ensayo se circunscribe sobre todo en el ámbito que incumbió a los emigrantes españoles que se asentaron en la isla del Caribe, el del mundo del campo y el de los amores, que es un motivo universal y del que es imposible zafarse, ya se cante, se escriba, se pinte o se esculpa en Cuba, España, Francia o Japón.

Cercana a la guajira flamenca anterior -por lo que tiene de memorial de esas frutas que en la época colonial en España ni se soñaban- está la que 


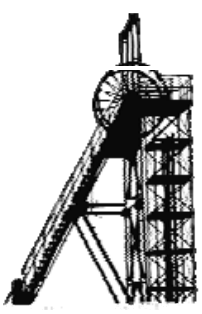

interpreta José María Valderrama, con un texto de Federico Alonso Pernía ${ }^{24}$, todo un alarde de buen gusto y conocimiento de la flora cubana (transcribo aquí la pronunciación literal de Valderrama):

\author{
Madre, a mí no me gusta el coco ${ }^{25}$, \\ ni el precioso canicai ${ }^{26}$, \\ ni la naranja calá ${ }^{27}$; \\ ni la ciruela tampoco. \\ El mango ${ }^{28}$ yo no lo toco \\ hasta que no está en sazón, \\ ni el precioso marañón ${ }^{29}$, \\ por ser la primera fruta. \\ El mango a mí sí me gusta, \\ verde, amarillo y pintón ${ }^{30}$.
}

Estas palabras relativas al léxico vegetal aparecen en muchas ocasiones, no son una rareza, sino una constante en las guajiras flamencas, como cuando Escacena canta en 1914 que se sentará al pie de un "jobo corpulento" para recordar desde allí a su amada, tal vez contemplando el mar. Pero es "jobo" y no "jopo" ("culo", "trasero" o "parte trasera o cola de un animal"), como se puede escuchar en otras

${ }^{24}$ En realidad, alterna una parte de la letra de su autoría con fragmentos de una guajira flamenca popular, de autor desconocido.

${ }^{25}$ Con seguridad, la palabra "madre" es un añadido del cantaor para poner énfasis en lo que se canta o para comenzar con fuerza el cante, puesto que con sus dos sílabas se rompe con la métrica octosilábica.

26 Una vez más, vemos que el cantaor equivoca la pronunciación del cubanismo, al decir "canicai" y no canistel (o "canistal", según algunas pronunciaciones) una fruta de color amarillo muy sabrosa.

${ }^{27}$ Naranja calada o naranja confitada, muy dulce, que solía servir de postre; también se regalaba a los niños en las fiestas más señaladas.

${ }^{28} \mathrm{Si}$ bien, esta fruta es de procedencia asiática, de India, en concreto, y la palabra original para referirse a ella era mankay, sacada de la lengua tamil.

${ }^{29} \mathrm{Al}$ marañón (también llamado cayú en varias lenguas indígenas) ya nos hemos referido en la nota número 23 de este artículo. Es cierto, tal y como recoge la letra de la guajira, que era y es una fruta muy apreciada, tanto por su sabor como por sus propiedades medicinales, ya que es muy rica en vitamina $C$, necesaria, entre otras cosas, para combatir el escorbuto o el resfriado.

${ }^{30}$ Con pintas, ya bastante maduro y blando, con lo que se acentúa su sabor dulce. No sabemos porqué al inicio de esta guajira al cantante no le gusta esta fruta para afirmar al final de la misma que le gusta de todas las maneras. Tal vez se nos ha "perdido" una fruta tropical con el paso del tiempo y se ha colocado el "mango", de fácil pronunciación, en las dos ocasiones. 
interpretaciones. El “jobo” es un árbol alto y frondoso (el Spondias purpurea, para más señas), cuya corteza y frutos tienen usos medicinales.

Así, si se ha dicho que para que el haiku sea haiku precisa de la palabra estacional o kigo (usando el término en japonés), la guajira flamenca no es tal si no se nombran las frutas, las flores o la fauna de la isla caribeña como marco en donde se ubica el ser humano.

Pero muchas de estas letras se han ido olvidando, se cantan cada vez menos o son raras en los repertorios de los cantaores y cantaoras de hoy. Sin embargo, la guajira flamenca más conocida por el aficionado tal vez sea la que se conoce precisamente por "La malanga" (un tubérculo muy apetitoso que se consume como la patata), en la versión ejemplar de Enrique Morente. Aunque la pronunciación de los nombres de las frutas y las flores no sea del todo correcta, el granadino pasa con nota la prueba. Comienza Morente con un "aquí" que no es sino la misma Cuba, donde se dan los alimentos y las flores que comienza a enumerar en la letra, como un catálogo desconocido para quien escucha:

Aquí la malanga crece,
rico manjar suculento,
y al rumor del blando viento
la rica caña se mece.
El ajonjoli parece
rica alfombra peregrina
y el mamey que se reclina
hacia la rama que toca
es dulce como la boca
de mi angelical Rufina

Hay cierto acuerdo en los escasos estudios que se han realizado hasta el momento en que la guajira flamenca más antigua, la que se considera como 16

\footnotetext{
31 En la región de Santiago de Cuba, por ejemplo, aún se cultiva el ajonjolí, cuya flor, de un violeta muy suave, crea un bello efecto de tapiz en la plantación.

${ }^{32}$ La Pouteria sapota. Deriva de la voz taína mami. Es un fruto carnoso, naranja en su interior, como un mango en cuanto al tamaño. Se puede tomar también en batidos, zumos, etc.
}

${ }^{33}$ https:// www.youtube.com/watch?v=tdgOYEObJe8 (última consulta: 01/06/2019). 


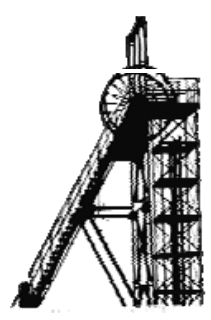

"guajira flamenca primitiva", ya marcaba la preceptiva de esta forma, ubicando

a quien canta en mitad de la naturaleza, escuchando el canto de las aves o contemplando la belleza de la exuberante vegetación (una letra que cantaron, entre otros, Pepe Marchena o Chano Lobato). Preciosa donde las haya, es un pequeño muestrario de los pájaros que un español podría contemplar en Cuba, además de deleitarse con su canto:

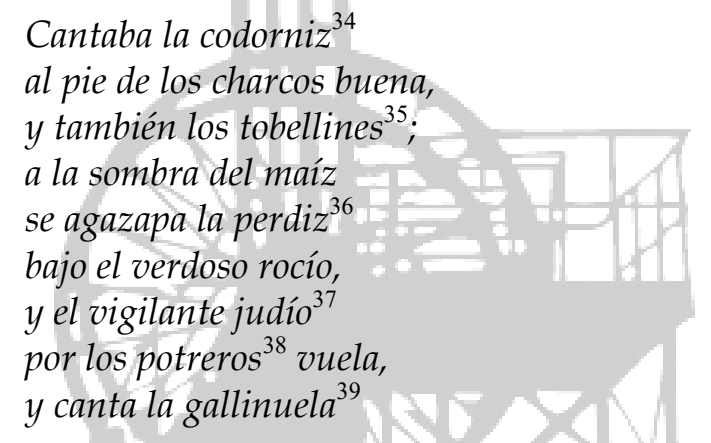

${ }^{34}$ En concreto, la variedad Colinus virginianus, que era muy valorada por los cazadores de la isla por su carne. Como dice esta guajira, le gusta rondar por las zonas húmedas, donde puede encontrar insectos con los que alimentarse.

35 El ave más difícil de identificar en la letra han sido esos misteriosos "tobellines" que canta Marchena, que no son sino los "tomeguines del pinar" o "senserenicos" (Tiaris canorus). Este precioso pajarillo de la guajira se conoce en España como "yerbero cubano", y era común que anidasen en los alrededores de las zonas de cultivos, es decir, la zona guajira por antonomasia. En los últimos años, esta ave endémica de Cuba está siendo criada en cautividad por su canto, silbante y cadencioso, aunque no se adaptan bien al cautiverio. No hay que confundirla con el "pájaro torbellino", de plumaje amarillo y negro, oriundo de varios países de Sudamérica, que posee un canto melodioso también. Aún hoy algunos de estos ejemplares son muy codiciados por los aficionados. Véase García Montaña (1987). Desafortunadamente, no he podido "encajar" la rima que precisan los versos segundo y tercero.

${ }^{36}$ La paloma perdiz cubana (Starnoenas cyanocephala) es una especie de ave columbiforme de la familia de las Columbidae, endémica de Cuba, es un ave hermosísima, de porte distinguido, plumaje azul en la cabeza, corbata negra y tonos pardos en el resto del plumaje, y que, en efecto, como bien nos dice la guajira, acostumbra a anidar al pie de las altas plantas del maíz o junto a los árboles de tronco fino.

37 Se refiere el autor de la letra al Crotophaga ani, o "garrapatero", según la nomenclatura de otros países de Centroamérica. Hay quien dice que lo de judío puede venirle por el color negro de su plumaje, que tiene que ver con la vestimenta tradicional ortodoxa del pueblo de Israel; o por lo abultado del pico en su cabeza, como la arquetípica nariz de los judíos, según la tradición popular; o por la conjunción de ambas cosas a la vez.

38 Terreno cercado, con pasto en su interior para alimentar al ganado, generalmente bobino.

${ }^{39}$ La Cyanolimnas cerverai o "gallinuela de Santo Tomás" (que es a la que se refiere la letra), es un ave endémica de Cuba que fue descubierta por el zoólogo español Fermín Zanón Cervera en 1927 en la Ciénaga de Zapata. Anida y vive en las zonas húmedas, en coherencia con lo que nos dice la guajira flamenca. En nuestros días se encuentra en grave peligro de extinción. 
en los márgenes del río.

Quien esto escribe ${ }^{40}$, quien lo canta está inserto en la naturaleza, embelesado por el trino o el vuelo de las aves, con la vegetación arropando todo, con el leve rocío como manto. Es una visión idílica, es la Arcadia caribeña; quien escribe -y canta- no interfiere con el ritmo de la naturaleza, tan sólo la contempla y se admira profundamente para luego comunicar lo que ha visto y sentido al auditorio.

Salvando la distancia entre pájaros en libertad y los que están enjaulados, esta exposición de aves exóticas me recuerda a un muy hermoso y conmovedor poema del escritor extremeño -pero criado entre las montañas y los valles de Marquetalia y Manizares (Colombia)-, Antonio María Flores (Don Benito, 1959), que pertenece a su poemario titulado Desplazados del paraíso:

La abuela tenía muchos
pájaros enjaulados
en el patio de las palmeras;
todos ellos de variado plumaje
y exquisito canto: -petirrojos,
sinsontes, turpiales, azulejos [...]

Tanto la guajira flamenca como el poema tienen a los coloridos pájaros como objeto de belleza admirable que, además de por su plumaje, deleitan con su canto al artista y aun lo inspira.

Transcribo ahora un último ejemplo de guajira flamenca que expresa con delicado detalle la apabullante flora y fauna de la isla caribeña:

Cuando va a salir el sol se tiñe el cielo de grana, $y$ el viento pone un rumor en la manigua ${ }^{42}$ cubana;

40 Lamentablemente, la inmensa mayoría de estas letras son anónimas, no conocemos los nombres de quienes las compusieron.

${ }^{41}$ Flórez (2006: 36).

42 Según el Diccionario de Americanismos: "Conjunto espeso de hierbas, maleza y arbustos tropicales" (última consulta: 19/06/2019). Durante las guerras de independencia, los cubanos 
el guacamayo en la rama se cubre de bello plumaje, los verdes cañaverales ${ }^{43}$, perfumados de rocío, con sus plumeros triunfales cubren la orilla del río ${ }^{44}$.

\section{España-Cuba-España: amor guajiro entre dos continentes}

Sostenidas, fructíferas, pasmosas, complicadas muchas veces, fluidas otras... así han sido las relaciones entre la preciosa isla del Caribe y España. No se trata aquí de redactar un manual de historia sobre este tema, pero sí daremos algunas fechas importantes, como la del 27 de octubre de 1492, cuando Cristóbal Colón llega a Cuba, o la del 1 de diciembre de ese mismo año, cuando el almirante hunde la denominada "Cruz de Parra" en la bahía de la que es hoy la ciudad de Baracoa, fundada como tal en 1501 por el cuellarano Diego Velázquez, que también fundará las ciudades de San Salvador de Bayamo (en 1513), Trinidad (en 1514) o Santa María del Puerto del Príncipe, la actual Camagüey (también en 1514). Avanzando en el tiempo, en 1728, con la autorización del papa Inocencio XII y el rey Felipe V de España se inaugura en La Habana la Real y Pontificia Universidad de San Gerónimo de La Habana (hoy Universidad de La Habana), de cuyas aulas salieron personalidades tan notables como Ignacio Agramonte, Dulce María Loynaz o Fidel Castro Ruz.

Lo que sí resaltaremos en este breve apartado (porque luego trataremos sobre ello más en profundidad) es que, paulatinamente, diferentes productos alimenticios y tecnológicos de Europa se fueron asentando en la isla (comidas, animales, métodos de cultivos e irrigación, fundición de metales...), y, del mismo modo, también Cuba, como el resto de tierras descubiertas en América,

solían propiciar escaramuzas y emboscadas a las tropas españolas en estos terrenos impenetrables.

43 Se trata aquí de la caña de azúcar, uno de los cultivos más famosos de la isla. Los plumeros serían la parte superior o panícula de dicha planta.

44 https:/ / www.youtube.com/watch?v=1yE3q2T31LY (última consulta: 19/06/2019). 
se hizo un lugar en el viejo mundo, sobre todo como afamada productora de un tabaco de primera calidad, cuidadosamente manufacturado. Pero también llegó de allende el mar el cacahuete, el cacao, la patata, el tomate, el frijol o el maíz. No obstante, curiosamente, lo que luego dio fama a la isla, el café $e^{45}$ y la caña de azúcar, llegó en los barcos europeos (el café proviene del Este africano, mientras que la caña es originaria del Sudeste asiático y Nueva Guinea), aunque en la isla antillana lograron un carácter muy personal.

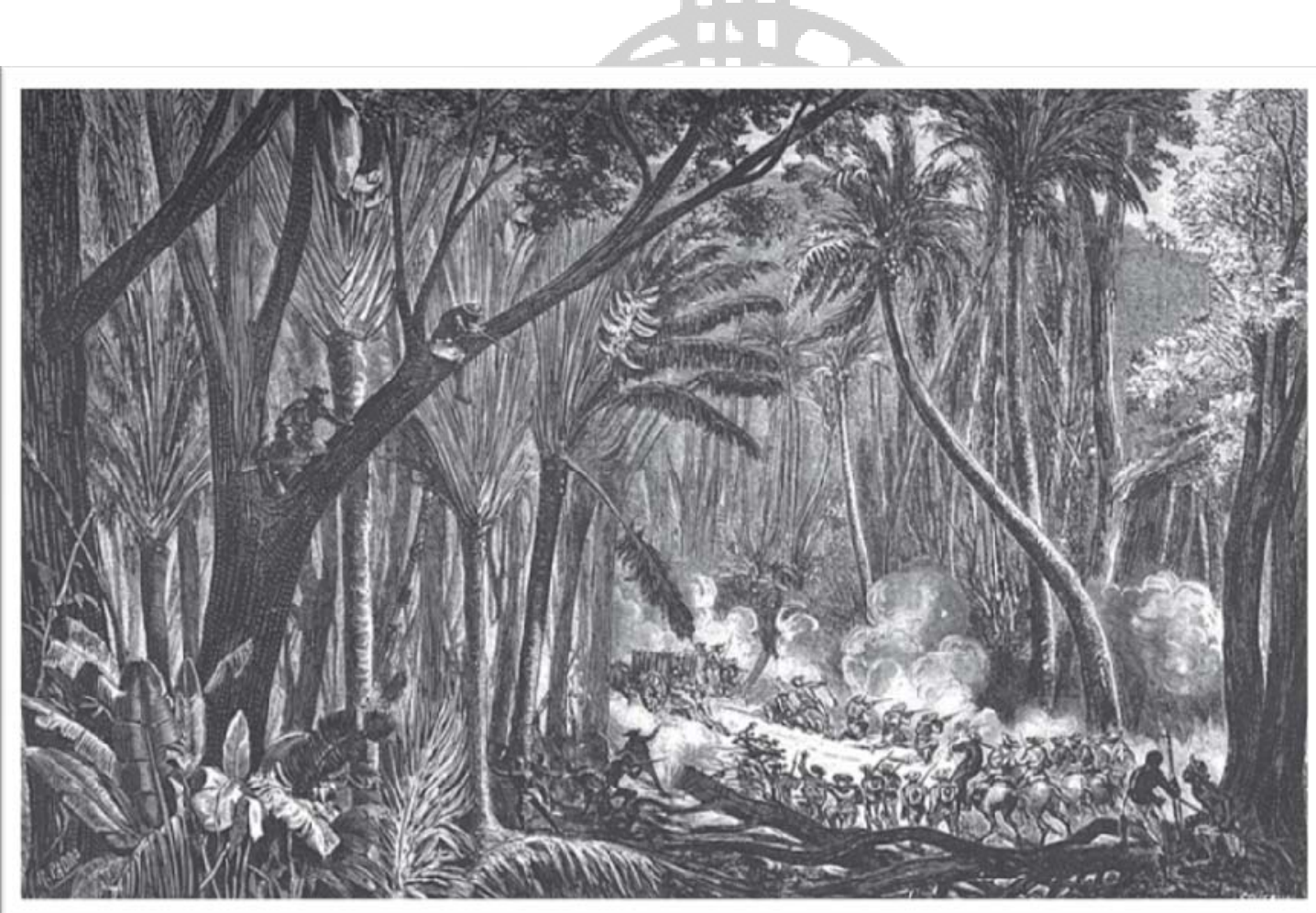

Imagen 1. "Isla de Cuba: un combate en la manigua"

(La Ilustración Española y Americana, 16 de marzo de 1872, p. 169)

Durante los siglos XVIII y XIX las relaciones son cada vez más convulsas. España yigila más que cuida de una de sus colonias más queridas. Cuba se revuelve, comienzan varios intentos de alzamientos que concluirán con la independencia del país en 1898, eso sí, con el apoyo de más de 300.000 voluntarios o regulares estadounidenses en las filas de los cubanos. Una

\footnotetext{
45 Aún hoy el café que se produce en la región de Sierra Maestra es muy valorado a nivel mundial por los expertos de esta bebida.
} 


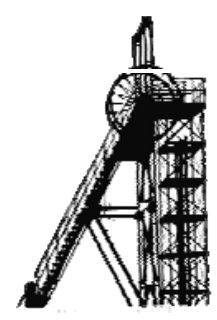

posición que en España se vio como de total pretensión hacia la isla ${ }^{46}$ y que tuvo una gran relevancia en la prensa satírica y en otras publicaciones españolas del momento, puesto que la pérdida de las últimas colonias se vio como un triste y deshonroso final al esplendoroso pasado de España, en cuyos dominios "nunca se ponía el sol".

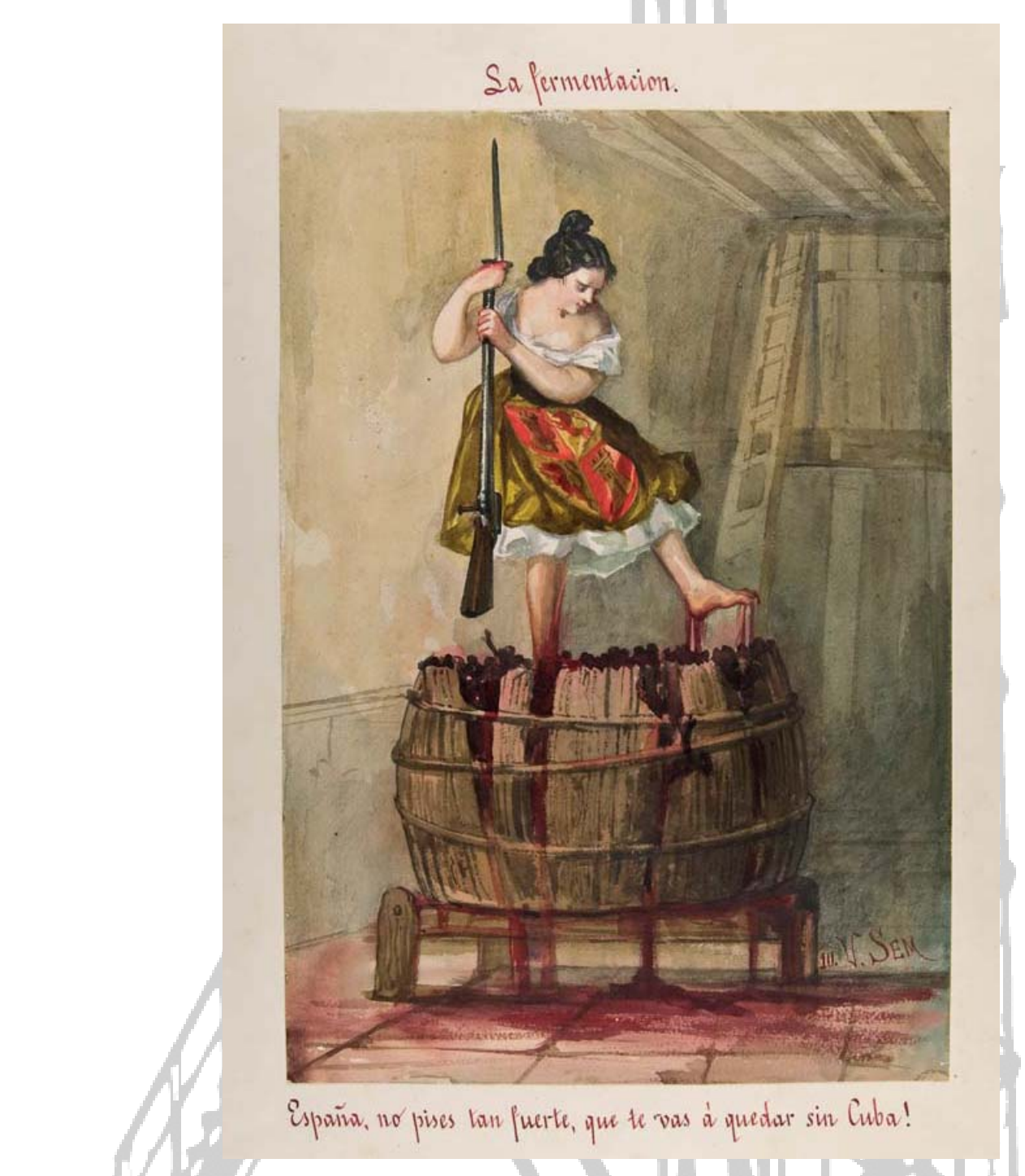

Imagen 2. “España, no pises tan fuerte, que te vas a quedar sin cuba!" (Burdiel, 2012: 97)

${ }^{46}$ Véase lo recogido por Jordi Siracusa en su novela histórica Adiós, Habana, adiós (2005). 
La figura representada por la imagen 2, sacada del mordaz álbum titulado Los Borbones en pelota ${ }^{47}$, juega con la rueda de los significados cuando, al pie de la estampa, podemos leer que la indicación precisa que se le da a España (representada como una mujer que empuña un fusil) es que no pise tan fuerte la uva, esto es, que no exprima con tanta saña el fruto o terminará por romperse la cuba donde se deposita el jugo, que viene a simbolizar la colonia española del Caribe.

Esta relación de los españoles para con Cuba, tan antigua, tan a flor de piel, fue la que generó las letras de las guajiras flamencas. Al margen de la naturaleza y el amor (a lo que luego nos referiremos), algunas de ellas hablan de los soldados de aquella guerra salvaje, que murieron lejos de España añorando todo lo que dejaron allí. Así se retrata la vida de cuartel en estas preciosas guajiras flamencas cantadas por Arcángel -dotado de una voz óptima para este palo, en mi opinión- y que aparecen recogidas en el film de Carlos Saura Flamenco (de 2010):

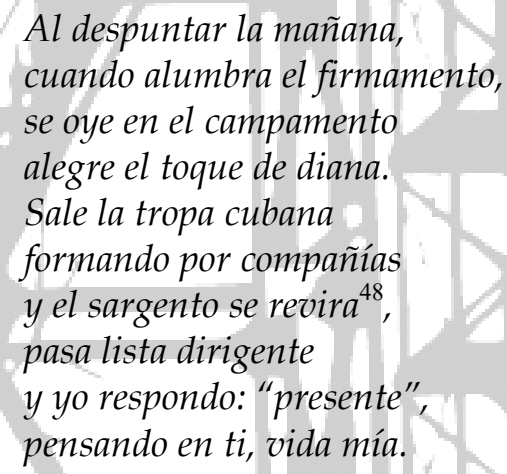

En varias de estas letras caribeñas (y al margen de la guajira flamenca), incluso aparecen/los nombres de los militares involucrados en este largo conflicto bélico de la independencia cubana, como cuando se canta:

\section{En lo alto de una loma}

\footnotetext{
${ }^{47}$ Atribuido a los hermanos Valeriano y Gustavo Adolfo Bécquer.

48 Un curioso verbo que en Argentina y en Uruguay quiere decir "se enfada", "se enoja" o, mejor, "volverse rápidamente contra alguien", pero en Cuba tiene el sentido de "revelarse" o "indisciplinarse". Sin duda, por el contexto de la letra, nos quedamos con las acepciones dadas en los países de América del Sur.
} 
estaba Quintín Bandera49, desafiando a la tropa con un cañón de madera. Yo le pregunté si era un insurrecto mayor y me dice: "no, señor, yo defiendo mi bandera"50.

Todo esto nos proporciona una idea de cómo los sucesos históricos embargaban las manifestaciones artísticas populares, tales como la música, la canción o la prensa del momento.

Dejando a un lado el campo de batalla, y como ya avanzábamos, el amor y la vida en el campo ocupa el grueso de las guajiras flamencas. Así, el tema del rechazo amoroso sufrido en España y el del encuentro con las mujeres cubanas (las mulatas, casi siempre) son dos de las constantes en las letras, tal y como aparece, por ejemplo, en las que canta "el Niño de la Huerta":

$$
\begin{aligned}
& \text { Una flor que yo corté, } \\
& \text { que llaman pensamiento, } \\
& \text { me recordó los tormentos } \\
& \text { que me causó una mujer. } \\
& \text { Pero a Cuba me marché } \\
& \text { para probar mi fortuna } \\
& \text { sin esperanza ninguna, } \\
& \text { y una cubana encontré, } \\
& \text { y al brindarle mi querer } \\
& \text { me quiso como ninguna51. }
\end{aligned}
$$

Así, según el contenido de guajiras flamencas como estas, en la comparación entre la mujer española y la cubana, por cariñosa, delicada, mimosa o zalamera, la cubana gana siempre. Embelesa a los españoles con su

\footnotetext{
${ }^{49}$ José Quintino (Quintín) Bandera Betancourt (1834-1906), general cubano que combatió en las tres guerras de independencia contra España. Aunque de temperamento difícil y con poca cultura, fue respetado entre sus soldados y temido por sus adversarios. Hombre de principios férreos, su palabra era ley; ascendió de soldado a general pasando por todos los empleos del escalafón militar. Una vez terminó la denominada Guerra Chiquita (1879-1880) no aceptó ningún cargo público ni honores, llegando a trabajar de barrendero.

${ }^{50} \mathrm{En:} \mathrm{http://canteytoque.es/letrastodas.htm} \mathrm{(última} \mathrm{consulta:} \mathrm{14/06/2019).}$

51 En: https://www.flamencoviejo.com/nino-de-la-huerta-una-flor-que-yo-corte-guajira.html (última consulta: 14/06/2019).
} 
piel morena y hace olvidar a las novias o las esposas que dejaron en España, tiene un hablar amable y siempre tiene una amorosa caricia que regalar. Su boca, junto con las frutas cubanas, comparte el adjetivo de "dulce" o "bella". Una descripción muy entregada de la mulata es la que hace Juanito Valderrama cuando canta:

$$
\begin{aligned}
& \text { Es la mulata un terrón } \\
& \text { de azúcar, canela hecho } \\
& \text { que arrimándoselo al pecho } \\
& \text { quita el mal de corazón. } \\
& \text { Ella vive con el don } \\
& \text { y a ningún hombre maltrata } \\
& \text { y si la llaman ingrata } \\
& \text { es más dulce que la uva } \\
& \text { del azúcar52 que hay en Cuba, } \\
& \text { la mejor es la mulata53. }
\end{aligned}
$$

Pero no sólo es el varón el que canta las bondades y la belleza de las gentes del Caribe. Existe también la letra de una guajira flamenca antigua, tal vez una de las más antiguas, que hoy apenas se conoce o se canta, y en la que el protagonista no es un hombre, sino una mujer, toda una aventurera española en La Habana, en donde narra su aventura amatoria con un negro cubano:

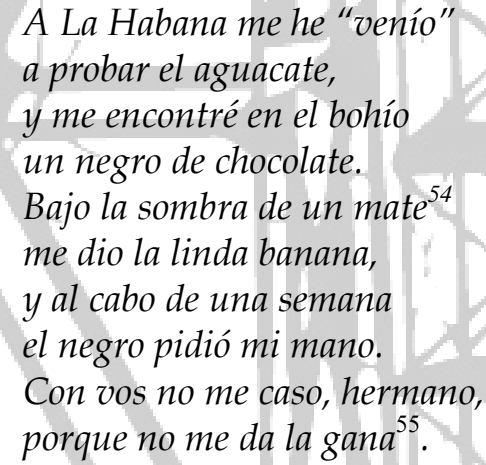

\footnotetext{
52 No se refiere a la uva que conocemos nosotros, fruto de la vid, sino a la Coccoloba uvifera o "uva de playa". En Cuba también se llama "guiabara". Su fruto es carnoso, jugoso y dulce, de color verde y de fuerte aroma y muy buen sabor. Tiene una única semilla grande. Se suele utilizar para confeccionar mermeladas, para hacer batidos y postres en varios países caribeños.

${ }^{53}$ https://www.youtube.com/watch?v=Nkbr6YdOwZU (última consulta: 16/06/2019).

54 Se refiere al caesalpinia crista o "mate de costa". Es una planta trepadora leñosa que llega a alcanzar los seis metros de alto, con abundantes hojas de un bonito color verde claro.
} 


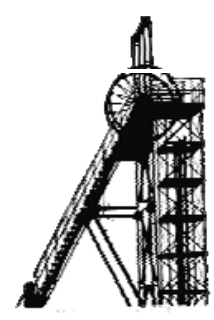

El elemento picarón, el ingrediente erótico era el que nos faltaba en la fórmula de la guajira flamenca (presente también en formas poéticas anteriores), y aquí lo tenemos y muy bien definido. Una mujer española marcha a Cuba a probar el aguacate (no sabemos si es una alusión al sexo masculino o al femenino ${ }^{56}$ ), el caso es que al entrar en su cabaña (bohío) en el campo conoce a un "negro de chocolate" que le ofrece "una linda banana". Como sucede con otras letras de guajiras flamencas, la española (como los varones españoles) rehúsa el casarse con el negro (o con la mulata o la guajira), aunque acepta de buen grado que sean amantes. Muy a colación viene la letra de otra guajira flamenca en la que el hombre español es quien decide el rumbo que tomará la relación con la muchacha cubana, a quien no se le permite decidir nada:

\section{[...] si te muestras placentera tú verás el cielo habanero ${ }^{57}$, tendrás coche y calesero y vivirás a mi abrigo, pero casarme contigo, eso será si yo quiero $[\ldots]^{58}$}

En definitiva, todo esto nos recuerda a la vigencia de la denominada "pureza de raza", quizá por ese conservadurismo que en nuestra sociedad ha estado más presente de lo que los propios españoles pensamos, por el que tener amantes o hijos bastardos se podía comprender o tolerar, pero no una unión por la Iglesia con una persona de raza distinta.

Pero, volviendo a la letra de la mujer española en las colonias, según la respetada opinión del historiador Salas Perea,

55 En: http://elcandilflamenco.blogspot.com/2007/04/los-cantes-de-ida-y-vuelta.html (última consulta: $14 / 06 / 2019)$.

56 Según el Diccionario de la RAE, del náhuatl ahuacatl ("fruto del aguacate, testículo"); en: https://dle.rae.es/aguacate?m=form (última consulta: 14/06/2019).

57 Seguramente se trate de una humilde chica de provincias a quien el español le ofrece la posibilidad de viajar y asentarse en la capital de Cuba.

${ }^{58}$ https://www.youtube.com/watch?v=Nkbr6YdOwZU (última consulta: 16/06/2019). 
en oposición a la conducta del hombre, que en Indias abandona muchas inhibiciones y se olvida de la mujer e hijos que dejó en España, la mujer española actuó en el sentido absolutamente inverso. Voluntariamente no se mezcló con el indio porque ello suponía su desprestigio social y el desprestigio de sus hijos, que saltaban hacia atrás en la escala de valores de aquella sociedad naciente. Es posible que hayan existido relaciones voluntarias y hasta algunos matrimonios, pero resulta evidente que el mestizaje lo realizó el varón español, como gesto voluntario $[\ldots]^{59}$.

Inspiradas en el amor entre una mujer española y un cubano están las denominadas guajiras "marcheneras" (único ejemplo que he encontrado de esta tipología hasta el momento), de métrica muy irregular si la comparamos con el resto de ejemplos, que -como dijimos-se ajustan (con alguna libertad) a la de la décima o espinela, y que canta María López Tristancho "Argentina", que, lamentablemente, no he podido ubicar en el tiempo ni saber más sobre su origen o recorrido, por más que he buscado en diferentes archivos. En esta letra es una "guajira española" la que nos confiesa que un cubano la traiciona por una mujer "de mejor color" (tal vez una mulata), pero, como dice el refrán, "no hay mal que cien años dure", ya que un hacendoso guajiro se enamora de ella, aunque no sabemos cómo termina la historia:

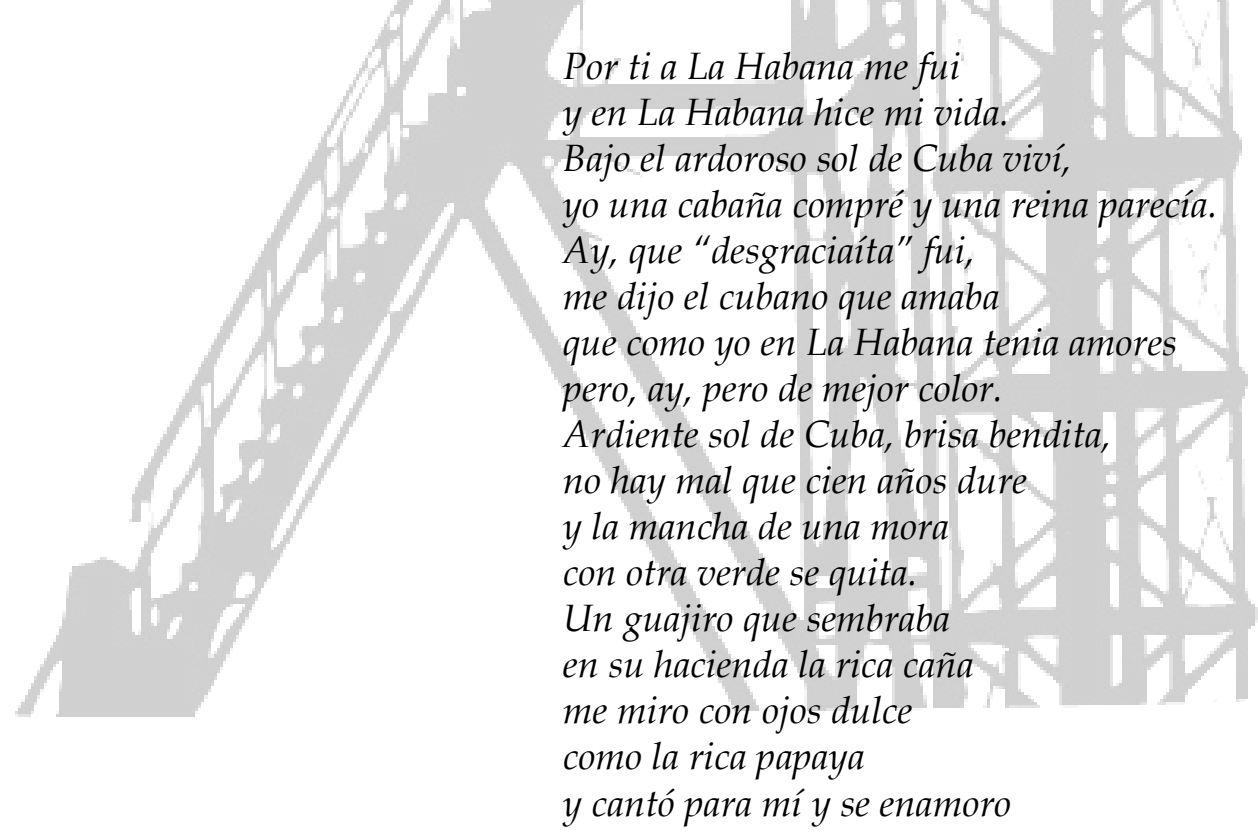

${ }^{59}$ Véase Salas Perea (2000: 572). 
de esta guajira de España60.

Aunque no siempre se canta al amor feliz o la contemplación de una mujer hermosa que entrega su pasión y da la felicidad al emigrante español. En unas muy pocas guajiras flamencas, como las que canta Manuel Escacena, el protagonista es el desamor, que tiene como escenario esos parajes verdes, de vegetación apabullante, en donde el amante se duele, en un diálogo expresado entre el español peninsular y el léxico cubano:

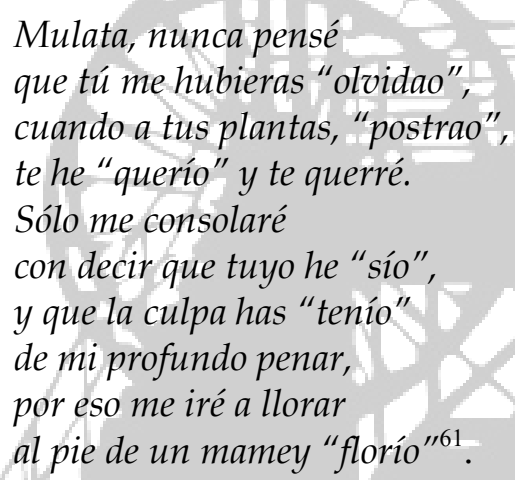

Como vemos, Cuba y sus mujeres son un territorio exótico y exuberante para los españoles, y la guajira es, tomando la definición de las palabras escritas por José Martí (1853-1895): “hacer cigarros y versos". José Martí, "padre de la revolución”, utiliza magistralmente el término guajiro y le da un significado (o una biosfera) que nosotros hacemos nuestra para este ensayo, cuando narra en su artículo titulado "Versos verdaderos" un hermoso embelesamiento creativo en el entorno rural. En mitad de la naturaleza se puede encontrar la más honda poesía, se puede escribir sobre ella y dentro de ella. Aunque extensa, creo que merece la pena leer la cita en cuestión, que concluye con un poema que sigue la estructura de la guajira cubana y que sería fácilmente musicable con acento flamenco:

Marco Morales, hombre hoy de casa de lujo, ganada a puño en la soledad yanqui, recuerda sus tiempos de mozo, allá en Barajagua ${ }^{62}$, donde "le dieron el tiro de muerte al

\footnotetext{
${ }^{60}$ En: https://www.youtube.com/watch?v=GJtT37AMWl4 (última consulta: 20/06/2019).

61 En: https://www.youtube.com/watch?v=e0jP80LMNUg\&t=155s (última consulta: $17 / 06 / 2019)$.
} 
brigadier José González, tabaquero y maestro de azúcar". También Marcos, de muchacho, componía décimas, antes de saber leer, décimas de amoríos para los campesinos, de "conquistar" y de "reconquistar". Y cuenta que cuando llegó una vez con su padre a una vega, a comprar del mejor tabaco que había, del de Manícaragua ${ }^{63}$; y vio a una muchacha, que se quedó dormida, debajo de un árbol, "uno de esos tipos preciosos de la naturaleza". Al verla, me inspiré; y ella, al sentir los caballos, se despertó. Allí mismo, con mis catorce años salvajes, escribí esta décima al salir, esta increíble décima:
En una fresca mañana
de un florido mes de abril,
donde el céfiro sutil
agita la palma indiana,
una guajira lozana,
más hermosa que una jagua,
bajo una hermosa yamagua ${ }^{65}$
medio dormida la hallé,
y al verla dije: " Esta sí es
la flor de Manicaragua! $!^{66}$

\section{La guajira como testimonio del amor interracial}

Como ya hemos comprobado en los ejemplos anteriores, si algo predomina en las letras de las guajiras flamencas es la fascinación que en ellas encontramos tanto por la belleza de la tierra cubana como por la de sus mujeres (por ejemplo, el término mulata -asociado a belleza, hermosura o dulzura mestiza- es muy utilizado). Su poética es la del cante flamenco que se encuentra, como se encontraron los españoles, con los distintos pueblos del Caribe, con nuevos ritmos, dando lugar a un palo mestizo, de son pausado, acompasado, sereno y hermoso, que suena dulce en el oído de quien lo escucha,

62 Localidad perteneciente al municipio de Cueto, en la provincia de Holguín.

63 Se trata de un municipio y un pueblo de la Provincia de Villa Clara. Es famoso por su tabaco y también por su café.

${ }^{64}$ Genipa americana. Árbol de entre 8 a 15 metros de altura, de hojas alargadas y verdes y con unas vistosas flores rojas, blancas o amarillas de cinco pétalos.

65 Árbol muy común en bosques, orillas de ríos y terrenos bajos o de mediana elevación, pero donde siempre se contenga la humedad. Pueden llegar a alcanzar hasta los veinte metros de altura.

66 Martí (1991: 214). 


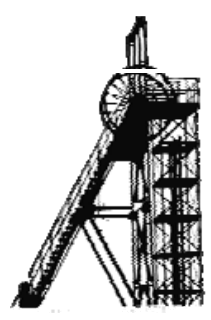

con una cadencia por la que navegan, dándose la mano, el español y el argot de los emigrantes (perrera, galbana, la pronunciación propia de Andalucía, etc.) con las palabras propias de las lenguas indígenas, que, luego, a su llegada a España, se han seguido cantando (con mejor o peor pronunciación) por boca de nuestros cantaores y cantaoras.

En cuanto a sus orígenes, existía ya un tipo de canción, acompañada normalmente con una o dos guitarras y varios instrumentos de percusión, y que en Cuba se llamaba precisamente así, "guajira", donde se cantaban los amores y los quehaceres de la vida campesina. "Mi bohío", cantada por Celina y Reutilio, que aparece en su álbum Perlas cubana, sería el mejor ejemplo de este género. Y es, con otro ritmo, lo que se canta en las guajiras flamencas en esencia: la belleza de una criolla o mestiza que vive rodeada, aun con humildad, de una vegetación exuberante con la cual se confunde, y hasta ella llega el español, el extraño, a "descubrirla" mientras trabaja la tierra o cuida de su ganado:

En un potrerito entré, me encontré con una indiana que se llamaba Juliana, su "apellío" no lo sé. Yo mi caballo solté, las buenas tardes le di y le dije: "vengo aquí67, vengo buscando los bueyes", y me contestó: "mameye, usted a quien busca es a mí6".

Ese "mameyes" que se canta aún (recuérdese la memorable versión de Enrique Morente) no sería sino una nueva alusión a otra fruta caribeña, el mamey, una deliciosa fruta tropical de forma ovalada, cáscara fina y semilla negra, de pulpa cremosa de color naranja-rojizo, aromática, suave y dulce.

${ }^{67}$ En otras versiones se pronuncia "negó aquí", "pongo aquí" o "vengo acá", que carecen de sentido o rompen con la rima obligada de la guajira. Proponemos como solución el "vengo aquí".

68 En: https://www.letras.com/enrique-morente/la-malanga-guajira/ (última consulta: $18 / 06 / 2019)$. 
Ahora bien, dicha fruta está revestida de una interesante lectura antropológica, puesto que mamey (en plural "mameyes") fue el apelativo que los cubanos pusieron a los soldados ingleses que en 1762 tomaron la ciudad de La Habana, quienes vestían su bien conocida casaca roja (redcoat), pareciendo ellos mismos mameyes abiertos por la mitad. Y mameyes se quedaron no sólo los ingleses, sino cualquier extranjero llegado hasta la isla, a los que se les atribuían las características de serviciales y simpáticos, pero también de algo aprovechados. Así, cuando vemos que una criolla se dirige a un extranjero con aire picarón no es inusual que lo haga con esta palabra.

\section{4. ¿Qué se canta en la guajira?}

La guajira flamenca no surge de la nada, sino que surge del encuentro con la música y la poesía cubana, en concreto con aquella más popular, la de los campesinos en su día a día; cristaliza en estas letras y consigue ser una estampa de cómo vivían los españoles, en ocasiones, logrando una muy vívida imagen, como sucede con la siguiente letra:

\section{Tengo mis pobres hogares, bella y adorada Lola, aquí está mi casa sola como la piña en el río, y entre hierbas y rocíos, de barro, cubes y guano, tengo yo, triste cubano, mi solitario bohío' 9 .}

El barro de la letra hace alusión a las zonas insalubres, sin aceras o pavimentos, sin civilizar, propias de las viviendas aisladas de la época, los famosos bohíos (imagen 3). Por su parte, el cube es una especie de barbasco, un barro acuoso mezclado con trozos de raíces, hojas $u$ otras materias vegetales, apreciado como abono. El guano ${ }^{70}$ es un tipo de palmera, de grandes hojas

\footnotetext{
${ }^{69}$ En: http://canteytoque.es/letrastodas.htm (última consulta: 14/06/2019).

${ }^{70}$ Su nombre científico es Coccothrinax borhidiana.
} 


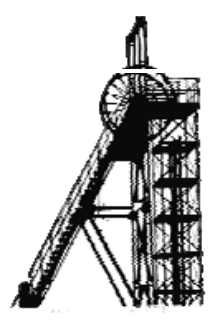

verdes, fuertes y de gran impermeabilidad, que se usaban para techar el bohío, aunque también se empleaban para trenzar sombreros y otros objetos de artesanía.

Comprobamos que la guajira flamenca es un retrato, es una instantánea del amor y de la naturaleza, una adaptación de lo que los españoles se encontraron allí y que luego se trajeron de vuelta en su imaginario sobre la isla: sustancialmente, una flora inabarcable y la dulzura y el amor diferente de las mujeres cubanas. Así, los temas primigenios eran esos dos: el amor $\mathrm{y}$ la naturaleza, muchas veces entremezclados, en otras, es sólo la naturaleza la que ocupa toda la letra. Unas guajiras flamencas primitivas que inmortalizase Pepe Marchena, con esa voz prodigiosa capaz de adaptarse a cualquier palo, dicen así:

$$
\begin{aligned}
& \text { Junto al palmar del bajio } \\
& \text { yo tengo un bohío } \\
& \text { cubierto de flores } \\
& \text { para la linda trigueña } \\
& \text { que con mi alma sueña, } \\
& \text { risueña de amores. } \\
& \text { Quiero platicar }{ }^{73} \text { contigo, } \\
& \text { debajo del cocotero, } \\
& \text { para que sepas, linda trigueña } \\
& \text { mia, cuanto te quiero }{ }^{74} \text {. }
\end{aligned}
$$

Una pura estampa de la naturaleza cubana, de sus sembrados y de quienes los habitan, y el amor, como en el poema referido por Martí, naciendo a la sombra de un árbol exótico con la naturalidad de una flor que se abre a la vida.

\footnotetext{
${ }^{71}$ Según el Diccionario de la RAE: "Adj. Dicho de un terreno o lugar bajo y que tiende, por su situación, a anegarse o a empantanarse. U. m. c. s. m."; en: https://dle.rae.es/baj\%C3\%ADo?m=form (última consulta: 22/06/2019).

${ }^{72}$ En Cuba, Honduras o Venezuela no tiene que ver con el color amarillo propio del trigo, sino con una persona de raza negra o de piel muy oscura. Véase la definición de la RAE en: https://dle.rae.es/trigue\%C3\%B1o?m=form (última consulta: 19/06/2019).

${ }^{73}$ Obsérvese que se emplea en la letra el verbo "platicar", usado en Latinoamérica, y no "charlar" o "hablar", preferido en el español peninsular.

${ }^{74} \mathrm{En}:$ https://www.youtube.com/watch?v=NkapCMXCDD0 (última consulta: 19/06/2019).
} 


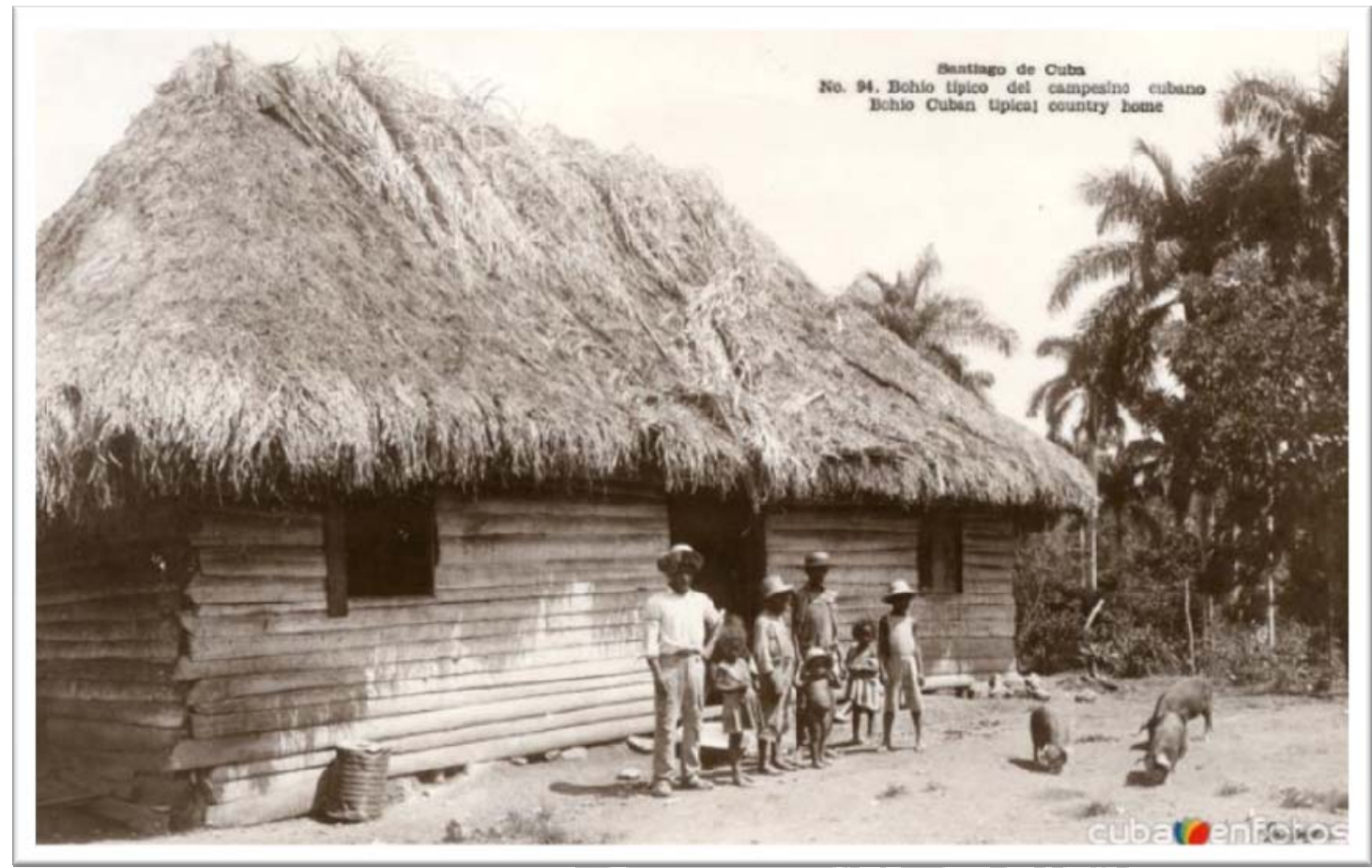

Imagen 3: Bohío típico de los campesinos cubanos

Fuente: http://www.cubaenfotos.com/antiguas/santiago-de-cuba/santiago-decuba/bohio-tipico-del-campesino-cubano-CU15431761000196

\section{El guajiro: el poeta del campo}

Tal y cómo aparecen retratados en el cuadro de Eduardo Abela (imagen 4), los guajiros eran hombres y mujeres muy ligados a la tierra, de indumentaria sencilla, normalmente blanca para protegerse del sol; sus aficiones eran las peleas de gallos, en donde se llegaba a apostar hasta la tierra y las casas, y la música y el baile. Vamos a quedarnos ahora un momento en el baile, en el momento en el que se descansa de las duras faenas del campo y se canta, se baila y se interacciona con otras personas. Allí, al margen de la fiesta, tiene lugar un hecho que, según podemos comprobar leyendo la bibliografía al respecto ${ }^{75}$, era un mal bastante común en la época: la infección de piojos y liendres, debido esto al contacto con los animales como caballos, ovejas, vacas y bueyes.

75 En: https://www.cubanet.org/internacionales/los-piojos-en-cuba-pasto-del-cuentapropismo-2/ (última consulta: $17 / 02 / 2019)$. 


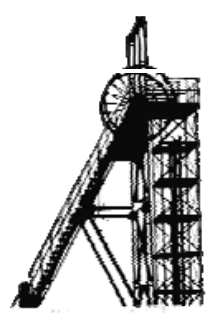

Aunque la palabra guateque tiene su origen en otra lengua del continente americano, quizá el mukuchi (lengua hoy extinta que se hablaba en la actual Venezuela ${ }^{76}$ ), en Cuba era una reunión animada, sobre todo de "negros y mulatos", muy duchos en sonar instrumentos y en cantar sones alegres, como aparece en la definición que hace Fernando Ortiz en su libro Nuevo catauro de cubanismos $^{77}$. Una reunión a la que uno podía llegar limpio y regresar a casa infestado de estos parásitos, tal y como dice una de las guajiras flamencas que más versiones tiene y que más se ha cantado hasta el momento:

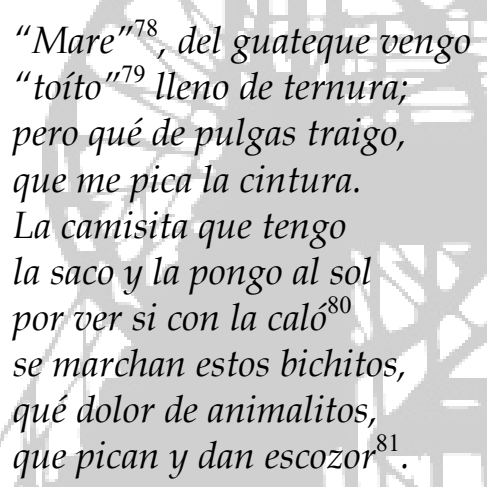

Una letra que ha tenido varias versiones, en las que la palabra "pulga" se ha cambiado por "bichitos" o "bichos", tal vez porque resultaba demasiado "cruda"; la camisa por "chaquetita"; en otras, la camisa "se tira y se pone al sol", etc. Existe incluso una variante mucho más refinada (y mojigata), ya que del guateque el protagonista no viene con piojos, sino con frío, lo que nos parece mucho más raro en el ambiente caribeño en donde se ubica:

Mare, del guateque vengo.

Mare, del guateque vengo

toíto lleno de ternura

de tanto frío traigo

\footnotetext{
76 Según: http://etimologias.dechile.net/?guateque (última consulta: 17/02/2019).

77 Ortiz (1985: 279).

78 "Madre".

79 "Todito".

80 "El calor".

${ }^{81}$ En: https://www.pinterest.it/pin/376121006364773717/ (última consulta: 18/02/2019).
} 
que me duele la cintura. La chaquetita que tengo, La chaquetita que tengo me la echo y me pongo al sol, por ver si su calorcito me alivia este dolor ${ }^{82}$.

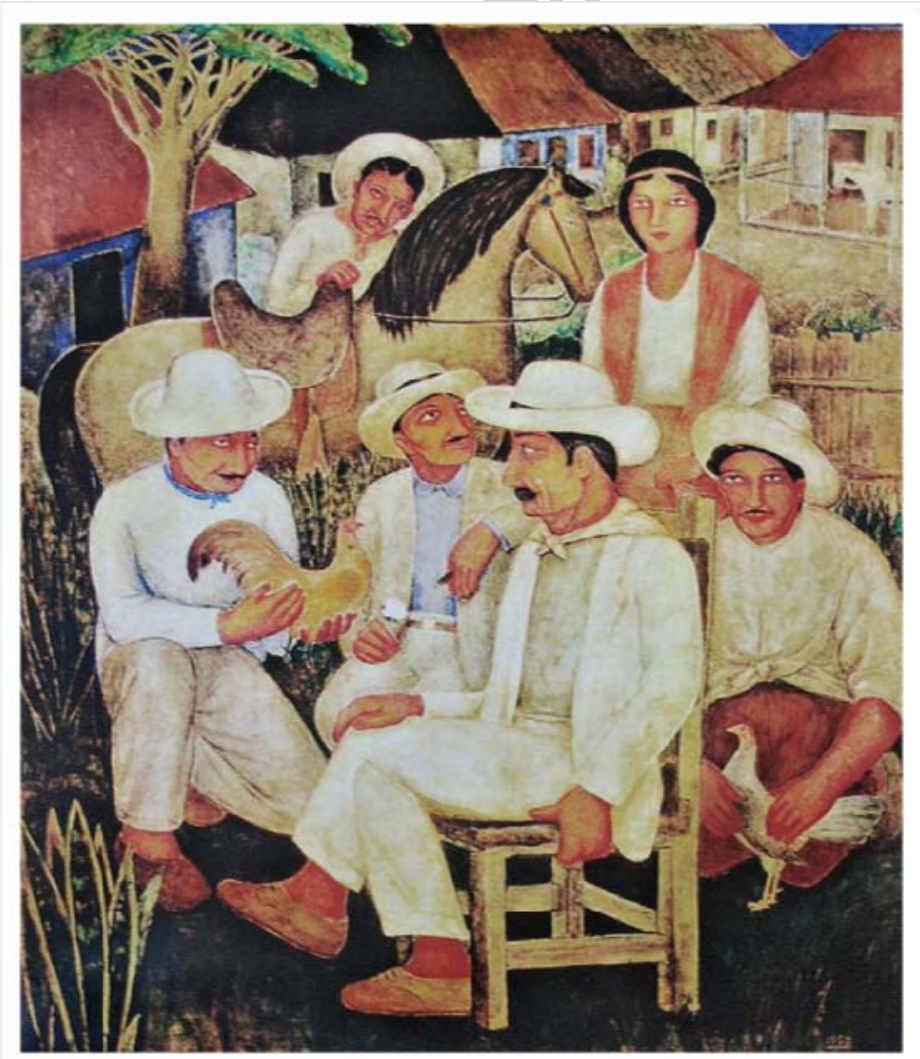

Imagen 4: "Guajiros", por el pintor cubano Eduardo Abela

(Fuente: http:/ / www.luzyartes.com/2012/07/guajiros-del-pintor-cubano-eduardo.html).

Evidentemente, cuando uno tiene frío se pone al sol, pero las fiestas cubanas, los guateques tenían lugar, principalmente, en los periodos de siembra y de recolección, coincidiendo con el buen tiempo, y cuando están más activos también los parásitos. Eso de extender la ropa al sol, con el calor, para que le diese una buena solajera, era un remedio antiguo, bien conocido por los campesinos (también en el sur de España), puesto que las pulgas y las garrapatas proliferan sobre todo en las zonas húmedas, y oscuras (cobertizos,

82 En: https://www.youtube.com/watch?v=Nf2WNbEh2Os (última consulta: 19/06/2019). 


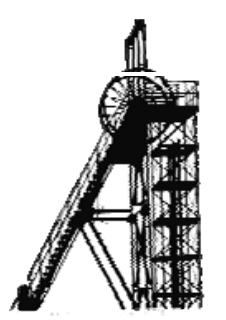

apriscos...) o escondidas en el ganado, como en los pliegues de la piel, orejas, ano... o en las articulaciones. Pero, el lector, como el cantaor/a, tiene libertad para elegir una versión $u$ otra.

Lo que parece, a la luz de todo lo analizado, es que las grabaciones más antiguas son las guajiras flamencas menos "adulteradas", las que más se aproximan a como fueron escritas. Una de las más hermosas, donde las palabras cubanas tienen una gran relevancia, son las que interpreta el ya aludido cantaor Manuel Escacena. Todo un reto para el investigador, donde un buen número de americanismos aparecen como desconocidos en nuestro vocabulario actual. Es la letra más oscura de todas las estudiadas aquí, el jeroglífico a descifrar más complicado de todos, donde en una única interpretación conservada más errores de pronunciación se producen, lo que consigue que no se pueda comprender el sentido completo de la letra. No en vano, en las poquísimas transcripciones de esta letra que se pueden encontrar en internet aparecen muchos huecos o signos de interrogación en el lugar en el que deberían aparecer los americanismos. Sólo ahora, después de más de tres meses de trabajo intenso dedicados en exclusiva a esta hermosa décima, nos atrevemos a dar una versión anotada de la misma (que tal vez no sea la definitiva, pero que dará algo de luz a futuras investigaciones y que pone esta letra en relación con el resto de guajiras flamencas que hablan del día a día y de la dura vida en el campo):

Ya mi humilde fantasía presume a cada momento, sobre un jobo corpulento comiéndome una jutía. Oiré crujir la varilla ${ }^{83}$, rescatada en el copey ${ }^{84}$

83 Palabra que no he podido identificar. Tal vez sea "varilla", un pedazo de madera para construir un cayado de buena madera.

${ }^{84}$ Según el Diccionario de americanismos: "m. Gu, Ni, CR, Pa, Cu:O, RD, PR, Co:N, Ve. Árbol de hasta $20 \mathrm{~m}$ de altura, de tronco grueso, hojas aovadas, flores blancas o rosadas y fruto redondo de pulpa anaranjada; su madera castaña rojiza se utiliza para postes y traviesas, y el látex que 
y haré que en el babiney ${ }^{85}$

el fango mi planta esparza,

aunque me rompa una zarza

mi sombrero de yarey.

En la guajira flamenca que canta Escacena el protagonista no está comiéndose "una judía", como algunos han argüido en algún foro de flamenco, para comenzar porque una sola judía no calma el hambre de un fornido hombre de campo, sino que lo que come es una "futía" o, más extendidamente, una "hutía". Una "futía" o "hutía" es un roedor del tamaño de un conejo, de carne sabrosa y altamente calórica. Aún son cazados por su carne en algunas zonas de Cuba, donde suelen cocerse en grandes cacerolas con productos como avellanas silvestres y miel.

El sonoro verso "que el fango su planta esparza" hace alusión a una de las etapas que el campo pide, la del abono, que se hace con el barro oscuro y rico en minerales del babiney, aunque, como nos dice la letra, éste se encuentre flanqueado de zarzas que pueden arruinar el sombrero de yarey $^{86}$ del campesino, un sombrero que es patrimonio cultural de la nación cubana, que no vuelve a lucir en ninguna grabación reciente y que servía para prevenir del sol $y$, a la vez, por lo poroso de sus fibras, secar el sudor de la frente ${ }^{87}$.

despide la corteza tiene usos medicinales. (Clusiaceae; Clusia rosea). (copei; cupey)". En: http://lema.rae.es/damer/ (última consulta: 19/06/2019).

85 Según el Diccionario de americanismos: "[En Cuba] lodazal, terreno lleno de lodo formado por el estancamiento del agua. En: http://lema.rae.es/damer/ (última consulta: 19/06/2019). Seguramente, este terreno al que alude la letra estaba poblado de zarzas y otras plantas salvajes.

${ }^{86} \mathrm{Al}$ parecer, se fabricó por primera vez en la provincia de Villa Clara.

87 El sombrero de yarey está tan interiorizado en la idiosincrasia cubana que, en muchas representaciones del orishá (deidad) afrocubano Eshù, éste aparece adornado con dicho sombrero. 


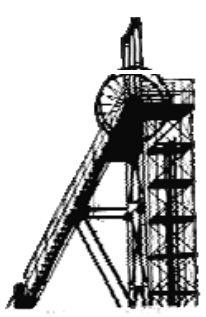

\section{Recapitulando: americanismos en las formas flamencas de "ida y vuelta"}

Al escuchar las guajiras flamencas el público más detallista se topará con palabras que no están muy presentes en el vocabulario del español peninsular (pero sí son frecuentes aún en el que se habla en la región del Caribe), y, es más, se topará con palabras que el cantaor/a pronuncia "muy a su manera", que han deformado del texto original, diluyendo el significado y, con ello, la capacidad de evocación de la letra. La definición de americanismo, según la quinta acepción del docto Diccionario de la Real Academia Española de la Lengua, sería: “m. Vocablo, giro o rasgo fonético, gramatical o semántico que pertenece a alguna lengua indígena de América o proviene de ella." ${ }^{88}$ Chirimoyas, piñas del siboney, maní, aguacate, mamey, uva del azúcar o la misteriosa malanga, están en las letras de las guajiras flamencas, de las que pareciera necesario decir algo más que sus nombres, por lo desconocido en la España de entonces o por los adjetivos que venían con ellas, como cuando se dice de la malanga que es un "rico manjar suculento". De las populares guajiras que cantó ese fenómeno del flamenco que fue Enrique Morente (1942-2010) nada podemos decir en cuanto a la ejecución, que se hará canónica -si no lo es ya- gracias a una voz de las que vienen a nacer, si es que nacen, una vez cada cien años. Lo que no nos deja claro del todo es el contexto. Y es que, quien escribe estas líneas, piensa que antes de ejecutar una guajira bien conviene que el/la cantaor/a dé unas nociones al público de lo que se va a escuchar. Desde luego que se disfruta con la música, pero para una completa comprensión de un tema que está ya algo alejado de nosotros no está de más explicar los entresijos de estas canciones mestizas. Por ejemplo, aquella que dice:

\section{[...] Aquí traigo esta mañana chirimoya y banana, aguacate y mamey y piña del Siboney,}

88 En: http://dle.rae.es/?id=2KBbsFD (última consulta: 25/02/2018). 
que es lo mejor de La Habana ${ }^{89}$.

Un canto del vendedor de fruta y un retrato de las calles populosas de la capital cubana, donde también se vendía la malanga, un tubérculo muy rico en minerales y muy valioso, que en la antigüedad se cambiaba incluso por otros bienes, tanto que en El Salvador aún hoy sirve para hacer referencia al dinero. Así, "tener malanga" es sinónimo de ser rico.

Y dejo para el final aquellas guajiras flamencas en donde el protagonista aparece con su cigarro encendido paseando por La Habana; unas de las más divertidas y festivas. Para comenzar, diremos que el vocablo "cigarro", que está tan asimilado en nuestra lengua, también procede de Latinoamérica, de la antigua lengua maya: siyar y cikar (la acción de fumar). La guajira flamenca en cuestión dice así:

Me gusta por la mañana,
después del café "bebio",
pasearme por La Habana
con mi cigarro ${ }^{90}$ "encendio".
Luego me siento en mi silla,
en mi silla o sillatón
y cojo yo un papelón
de esos que llaman diario
y parezco un millonario
de esos de la población.

La canción plantea un juego de apariencias del protagonista, que, sin tener un céntimo en el bolsillo, paseando mientras fuma y "cogiendo" un periódico, (que no leyéndolo) pareciera un millonario del lugar, caminando ufano por la capital.

La expresión de "café bebío", en Andalucía -pero también en Extremadura- significaba salir a trabajar habiendo tomado para desayunar tan sólo un café negro o, en el mejor de los casos con algo de leche, sin ningún acompañamiento sólido. “Llevo toda la mañana sólo con un café bebío" quiere

\footnotetext{
89 En: https://www.youtube.com/watch?v=Nkbr6YdOwZU (última consulta: 23/06/2019).

${ }^{90}$ En otras versiones, en lugar de la palabra "cigarro", aparece "tabaco".
} 


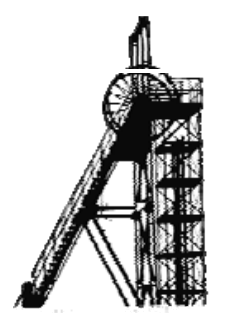

decir que no se ha ingerido nada más; así, el protagonista de nuestra letra sale a la calle sin haber tomado nada más que un café (debido a su pobreza), un producto que en Cuba era muy económico y estaba al alcance de cualquiera, para aparentar ser uno de los millonarios del lugar.

El sillatón, palabra ya en franco desuso, sirve para referirse a un asiento cómodo, un sillón, palabra por la que se ha cambiado en ocasiones a la hora de entonar estas guajiras flamencas. En México, por ejemplo, aún se mantiene la palabra sillatón, pero con el significado de "silla de ruedas".

\section{Coda}

No cabe duda de que nuestro flamenco contiene fragmentos tomados de otros lugares. La de la guajira flamenca es una zona exótica que recuerda la presencia de España en Latinoamérica, con alegría y con nostalgia a la vez, con amor y desamor. La música siempre ha sido un ejemplo de fusión, donde la mezcla funciona, donde el producto siempre sale enriquecido cuando se pone lo mejor de cada lugar y es, además, algo por lo que estamos unidos. A fin de cuentas, como cantó ese grande de Granada que fue Carlos Cano: "La Habana es Cádiz con más negritos, Cádiz es La Habana con más salero".

Pero no todo lo que lleva ritmo de guajira flamenca es tal cosa, lo mismo que toda forma breve, de más o menos 17 sílabas, tampoco puede considerarse haiku. Bajo el ritmo de estas canciones letras como la denominada "Guajira del borracho" pudieran parecer guajiras flamencas, pero no lo son en absoluto. La guajira flamenca tiene una idiosincrasia propia, muy hermosa, que precisa de cantar a y en la naturaleza, de sentirse inserto en ella, pero que aún está por estudiar y, por ende, por definirse. Este ensayo es sólo una pequeña muestra, tal vez una cata para el aficionado que quiera ir más allá de escuchar una guajira flamenca, o un trampolín para futuros estudios, una llamada de atención para filólogos y lingüistas. 
Así, esta ha sido una visión muy panorámica, una introducción apenas a un tema apasionante que aporta algunas pistas interesantes sobre cómo fueron las relaciones entre España y Cuba a través de la música, una expresión sincera y pura, más explícita que muchos gruesos prontuarios. Pero, por si el lector me pidiera una definición breve de la guajira flamenca, y como colofón rimado, se la doy gustoso en forma de guajira flamenca misma (un fragmento de ella), aquella que canta Felipe Lara y con mucho salero dice:

\section{En barcos de vela fueron mis abuelos a La Habana, y a la vuelta se trajeron esta guajira cubana ${ }^{91}$.}

\section{Bibliografía}

ACERO DuARTe, Luis Enrique (2000). Árboles, gentes y costumbres. Bogotá: Universidad Distrital Francisco José de Caldas \& Plaza y Janés.

Álvarez EstéveZ, Rolando y GuZMÁn PASCUAL, Marta (2010). La inmigración francesa en Cuba. Excelencias Turísticas, n. ${ }^{\circ} 123$ (en http://www.revistasexcelencias.com/excelencias-turisticas/excelencias123/la-inmigracion-francesa-en-cuba; última consulta: 09/06/2019).

ARES QUEJIA, Berta y AlESSANDRO, Stella (Coords.) (2000). Negros, mulatos, zambiagos: derroteros africanos en los mundos ibéricos. Sevilla: Escuela de Estudios HispanoAmericanos-CSIC.

BurdiEL, Isabel (2012). Los Borbones en Pelota. Zaragoza: Institución "Fernando el Católico".

CAÑIZARES, Dulcila (1992). La trova tradicional cubana. La Habana: Editorial Letras Cubanas.

CARMONA, Alfonso (2013). "Sobre la poesía flamenca y su métrica". Revista de investigación sobre Flamenco "La Madrugá", n 8, 2013, pp. 139-156.

CASIELLES, Armando Jaime (2010). África en la música cubana. Caribe, n. ${ }^{\circ} 45$ (en: http://www.revistasexcelencias.com/caribe/enhorabuenaconsuelo/musica/africa-en-la-musica-cubana; última consulta: 09/06/2019).

CASTEllanOS, Jorge y CASTELlanOS, Isabel (1994). El negro en la música cubana. Cultura afrocubana (vol. IV). Miami: Universal, pp. 265-396.

91 En: http://pedelgom.blogspot.com/2013/04/felipe-lara-77.html (última consulta: 19/06/2019). 


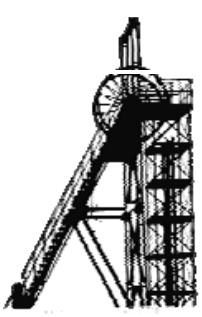

CAMPO TEJEDOR, Alberto del (2006). Trovadores de repente. Salamanca: Centro de Cultura Tradicional Ángel Carril.

Depestre Catony, Leonardo, Guerrero Ruiz, Pedro y PAstor Pastor, Brígida (2002). Glosario popular cubano: Estudio de cubanismos actuales. Lenguaje y textos, $n^{\circ}$ 20, 2002, pp. 139-160.

DíAZ PIMIENTA, Alexis (1998). La teoría de la improvisación: primeras páginas para el estudio del repentismo. Oiartzun: Sendoa Editorial.

FeIJóo GómEZ, Albino (1992). Quintas y protesta social en el siglo XIX español. Madrid: Ministerio de Defensa, 1992.

FlóreZ, Antonio María (2006). Desplazados del paraíso. Mérida: Editora Regional de Extremadura.

GARCíA MontAÑA, Florentino (1987). Las aves de Cuba: subespecies endémicas. La Habana: Editorial Gente Nueva.

GonzÁlez Bolaños, Aimée (2008). Poesía insular de signo infinito: una lectura de poetas cubanas de la diáspora. Madrid: Betania.

IGLESIA, Cristina (2000). La mujer cautiva: cuerpo, mito y frontera. Georges Duby (Ed.). Historia de las mujeres (Tomo III: del Renacimiento a la Edad Moderna). Madrid: Santillana, 2000.

LiNARES, María Teresa y NúÑEZ, Faustino (1998). La música entre Cuba y España (vol. I), Madrid: Fundación Autor.

LiNARes SAVIO, María Teresa (1999). El punto cubano. La Habana: Editorial Oriente.

MARTí, José (1991). Obras completas (vol. V: Cuba). La Habana: Editorial de Ciencias Sociales.

Moreno Fraginal, Manuel (1996). Cuba España, España Cuba, una historia común. Madrid: Crítica.

MOYA, Ismael (1959). El arte de los payadores. Buenos aires: Editorial Berruti.

NAVArro GarcíA, Jesús Raúl (Coord.) (2002). Cuba y Andalucía entre las dos orillas: Sevilla: Junta de Andalucía- CSIC.

NAVArro, TOMÁs, Tomás (1972). Métrica española. Reseña histórica y descriptiva. Madrid: Guadarrama.

OrTIZ, Fernando (1985). Nuevo catauro de cubanismos. La Habana: Editorial de Ciencias Sociales.

Ríos Ríos, Manuel (1997). Ayer y hoy del cante flamenco. Madrid: Istmo.

Rodríguez Cruz, Juan Carlos; Bezarra Neto, Luiz; Córdova Martínez, Carlos Antonio (2017). Origen y evolución del término guajiro. Revista Exitus, vol. 7, n 1 , pp. 427-440. 
SAlas PereA, Alberto Martín (2000). El mestizaje en la conquista de América. En Georges Duby y Michelle Perrot (Eds.). Historia de las mujeres (tomo III: Del Renacimiento a la Edad Moderna). Madrid: Santillana.

SARAlegui Platero, Carmen (1997). El español americano: teoría y textos, Pamplona, Ediciones de la Universidad de Navarra-EUNSA.

SIRACUSA, Jordi (2005). Adiós, Habana, adiós. Madrid: Nuevos escritores.

TRAPERO, Maximiano (1996). El libro de la décima: la poesía improvisada en el mundo hispánico. Las Palmas de Gran Canaria: Universidad de Las Palmas de Gran Canaria- Cabildo Insular.

Vega TosCANO, Ana (1997). Los cantes de ida y vuelta en el flamenco: la guajira. Revista de musicología, vol. 20, n², pp. 971-980.

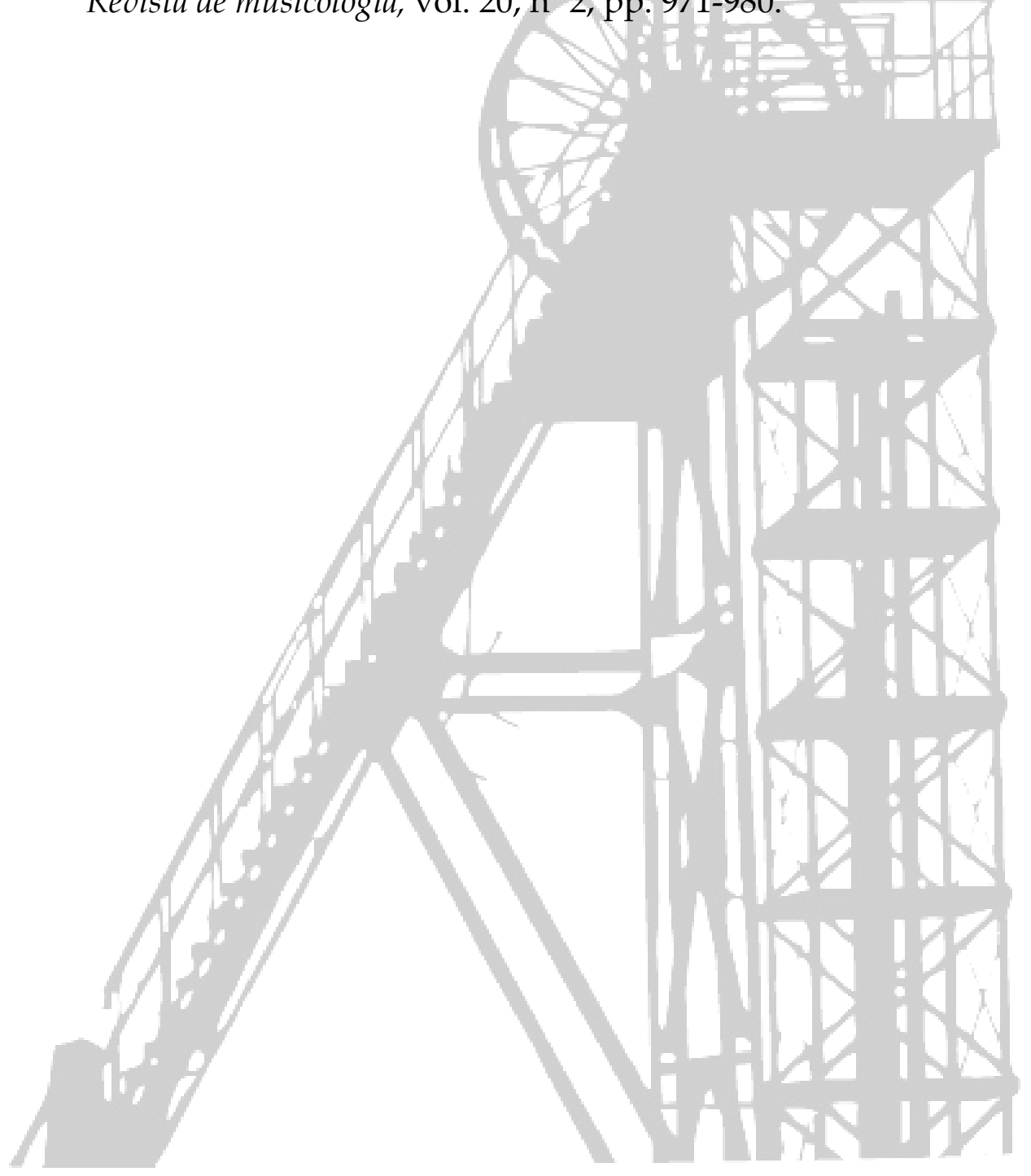




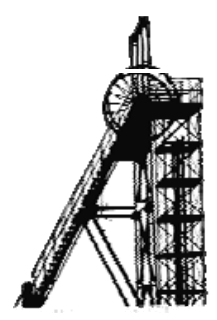

\section{Apéndice}

Americanismos que aparecen en las diversas guajiras flamencas tradicionales analizadas en el presente artículo (relacionados en orden alfabético):

Aguacate, babiney, bohío, canistel, cigarro, copey, cube, chirimoya, futía, guacamayo, guajira, guajiro, guano, guateque, malanga, mamey, manigua, marañón, mate, tomeguín, trigueño, turpial, yamagua, yarey.

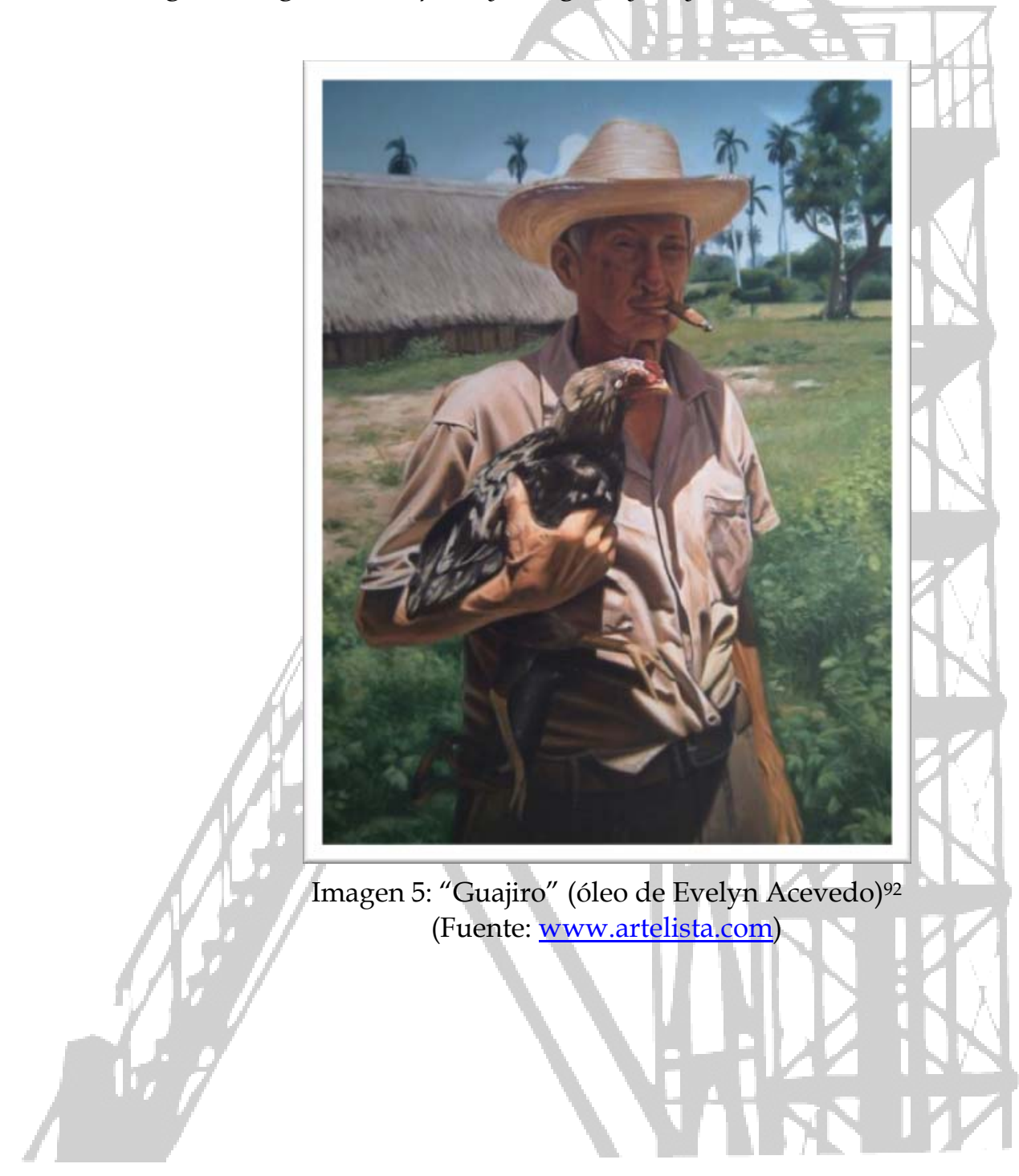

${ }^{92}$ Nótese el cigarro, sombrero de yarey y gallo de pelea en el brazo izquierdo; y tras él, un típico bohío guajiro. 